\title{
Synthesis and Evaluation of Antimicrobial Activities of New Piperidine Derivatives
}

\author{
Tanveer Mahamad Alli Shaikh 1,* (D), Yibrah Ammare 1(i) \\ 1 Department of Chemistry, College of Natural and Computational Sciences Mekelle University, Mekelle, Ethiopia \\ * Correspondence: tanveerchem1@gmail.com;
}

Scopus Author ID 8690415500

Received: 9.05.2020; Revised: 3.06.2020; Accepted: 4.06.2020; Published: 7.06.2020

\begin{abstract}
Nitrogen heterocycles with piperidine rings are the most prominent structural features and frequently utilized by pharmaceuticals. In this study, we have disclosed the synthesis of new compounds with piperidine motif. The synthesis of these derivatives was achieved using Wittig olefination, Oalkylation, and nucleophilic substitution reaction. The antimicrobial activity was performed by disc diffusion method utilizing Staphylococcus aureus as gram-positive and Escherichia coli as a gramnegative bacterial pathogen, respectively.
\end{abstract}

Keywords: N-Heterocycles; Piperidine; Antimicrobial; Wittig olefination; O-alkylation.

(C) 2020 by the authors. This article is an open-access article distributed under the terms and conditions of the Creative Commons Attribution (CC BY) license (https://creativecommons.org/licenses/by/4.0/).

\section{Introduction}

The heterocyclic compounds are known from the centuries and play an essential role in chemistry, biology, and medicine [1]. Moreover, molecules with the presence of heterocycles, both natural products and synthetic drugs, showed excellent bioactivity [2-6]. Over the past three decades, these structural features of heterocycles have been thoroughly exploited by researchers [7-9].

Among them, the nitrogen-containing heterocycles have attracted due to their broad applications in natural products [10-13], alkaloids [14], pharmaceutical drugs [15], or druglike molecules [16-17], synthetic building blocks [18-23], electronics, material science [2425], polymers [26], Dyes [27-28], and agrochemicals [29]. Interestingly, the saturated Nheterocycles are associated with certain advantages such as better solubility of drugs to enhance their metabolism [30-31], than the corresponding aromatic N-heterocycles. Mainly, the piperidine moieties are a fascinating class of N-heterocycles, found in therapeutic agents [3234], and chiral molecules [35-36], with significant biological activity, for example, antihypertensive, antibacterial [37-38], antimalarial [39], anticonvulsant [40], antiinflammatory [41-42], antiproliferative, antitubercular and antioxidant [43-44].

Due to the importance of the piperidine scaffold, several functionalized derivatives have been investigated to find the lead compound (Figure 1) [45]. Cinnamic acid derivatives such as esters, amides, and hydrazide have been exploited due to their essential antioxidant and anti-inflammatory activities [46-47]. Although a great variety of piperidine derived bioactive molecules have been studied, the combination of piperidine with $\alpha, \beta$-unsaturated esters (cinnamate) is not known in the literature. Earlier, we have reported the asymmetric syntheses of piperidine-based molecules [48-50]. We present here an efficient method to synthesize 
piperidine derivatives and investigation of their antimicrobial bioactivity against pathogens Escherichia coli as gram-positive and Staphylococcus aureus as gram-negative bacteria.<smiles>COc1cc2c(cc1OC)C(=O)C(CC1CCN(Cc3ccccc3)CC1)C2</smiles>

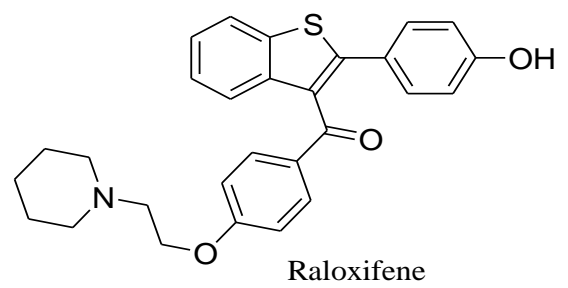<smiles>CC(C)(C)c1ccc(OCCCN2CCCCC2)cc1</smiles><smiles>Clc1ccc(OCCCOCCCN2CCCCC2)cc1</smiles>

Pitolisant

Figure 1. Lead drugs and bioactive molecules with piperidine core.

\section{Materials and Methods}

4-Hydroxy benzaldehyde, Wittig reagent [(carbethoxymethylene) triphenylphosphorane], and piperidine were purchased from Sigma-Aldrich, South Korea. The solvents and reagents (analytical grade) were procured from India, and it was used as such without any purification. The progress of the reaction was monitored using thin-layer chromatography (TLC), and the appearance of TLC spots was visualized by UV-lamp at 254 and $365 \mathrm{~nm}$. The purification of products was performed using a chromatographic method using 60-120 mesh silica gel and a combination of solvents hexane:EtOAc. All the obtained products were characterized using FTIR, melting points, ${ }^{1} \mathrm{H}-$ and ${ }^{13} \mathrm{C}-\mathrm{NMR}$ and DEPT NMR. Melting points (m.p.) were recorded on the MEL-TEMP instrument in closed capillaries without correction. A FT-IR spectrum has been recorded on Shimadzu 4000 FT-IR using KBr pellet. Bruker instrument has been utilized to measure ${ }^{1} \mathrm{H}-\mathrm{NMR}$ of synthesized compounds, including ${ }^{13} \mathrm{C}-\mathrm{NMR}$ at $400 \mathrm{MHz}$ for proton spectra and $100 \mathrm{MHz}$ for carbon spectra, respectively.

\subsection{Synthesis.}

2.1.1. Synthesis of 3-(4-Hydroxyphenyl)-(E)-ethyl propenoate (6).

A round bottom flask (100 mL) along-with magnetic bar, (Ethoxycarbonylmethylene) triphenylphosphorane (7) (10.45 g, $30 \mathrm{mmol})$ and deionized water $(60 \mathrm{~mL})$ was introduced successively. The resulting solution was stirred at $25{ }^{\circ} \mathrm{C}$ for 5 minutes. Then, 4hydroxybenzaldehyde $(\mathbf{8})(2.44 \mathrm{~g}, 20 \mathrm{mmol})$ was slowly added to the flask. Again the whole mixture was allowed to stir for 5 minutes at room temperature and further heated to $80-90{ }^{\circ} \mathrm{C}$ $(2 \mathrm{~h})$ with continuous stirring. The reaction was monitored with the help of TLC. After completion of the reaction, it was cooled to $25^{\circ} \mathrm{C}$, and then transferred to a separatory funnel, and $\mathrm{CH}_{2} \mathrm{Cl}_{2}(3 \times 40 \mathrm{~mL})$ was used as an extraction solvent.[51] The combined organics was treated with water $(15 \mathrm{~mL})$ and anhydrous $\mathrm{Na}_{2} \mathrm{SO}_{4}$. Removal of $\mathrm{CH}_{2} \mathrm{Cl}_{2}$ was carried out using a rotary evaporator resulted in the oil as a crude product. The crude product 6 was subjected to the chromatographic purification using 60-120 meshed silica gel, elution of 20\% EtOAc in $n$ hexane to provide 3-(4-Hydroxyphenyl)-(E)-ethyl propenoate in $85 \%(3.264 \mathrm{~g})$ as a colorless solid. 
Melting point: $68-72{ }^{\circ} \mathrm{C}$; FTIR in $\mathrm{KBr}\left(\mathrm{cm}^{-1}\right)$ : 680, 979, 1110, 1205, 1291, 1380, 1473, 1595 , $1610,1716,2922,3224 ;{ }^{1} \mathrm{H}-\mathrm{NMR}$ in $\mathrm{CDCl}_{3}(300 \mathrm{MHz}) \delta=7.58\left(\mathrm{~d}, 1 \mathrm{H}, \mathrm{H}^{\beta} \mathrm{C}=\mathrm{CH}^{\alpha} \mathrm{R}, J=16\right.$ $\mathrm{Hz}$ ), 7.42 (multiplet, 2H), $6.90(\mathrm{~m}, 2 \mathrm{H}), 6.30\left(\mathrm{~d}, 1 \mathrm{H}, \mathrm{H}^{\beta} \mathrm{C}=\mathrm{CH}^{\alpha}-\mathrm{R}, J=16 \mathrm{~Hz}\right), 5.40$ (brs, $1 \mathrm{H}$, H-O-Ar), 3.80 (q, 2H, OCH,$J 7.2 \mathrm{~Hz} \& J 6.8 \mathrm{~Hz}), 1.37$ (t, 3H, CH3, J 7.2 Hz \& J $6.8 \mathrm{~Hz}$ ); ${ }^{13} \mathrm{C}-\mathrm{NMR}$ in $\mathrm{CDCl}_{3}(100 \mathrm{MHz}) \delta=168.58,158.81,145.38,130.10,126.49,116.08,114.78$, $60.88,14.28$.

\subsubsection{Synthesis of (E)-ethyl 3-(4-(2-bromoethoxy)phenyl)acrylate (3).}

Wittig product 3-(4-Hydroxyphenyl)-(E)-ethyl propenoate (6) $(2.88 \mathrm{~g}, 15 \mathrm{mmol})$ was dissolved using $25 \mathrm{~mL}$ of dimethyl formamide. Then the resulting solution was allowed to stir at $25{ }^{\circ} \mathrm{C}$, and $\mathrm{KOH}(2.52 \mathrm{~g}, 45 \mathrm{mmol})$ was introduced in one portion. Subsequently, 1,2dibromoethane (5) $(4.133 \mathrm{~g}, 22 \mathrm{mmol})$ was introduced with the help of a syringe. This whole mixture was allowed to heat $\left(80^{\circ} \mathrm{C}\right)$ for $3 \mathrm{~h}$. The development of the reaction was monitored using TLC [52]. After completion of the reaction, the flask was cooled to $25^{\circ} \mathrm{C}$, extracted with EtOAc (40 mL x 3). Then ethyl acetate (EtOAc) layer was treated with anhydrous $\mathrm{Na}_{2} \mathrm{SO}_{4}$ followed by evaporation of ethyl acetate using a rotary evaporator. Thus the obtained crude residue (3) was subjected to chromatographic purification using a column packed with (60-120 mesh) silica gel and eluent as EtOAc:hexane (5\%) affording pure (E)-ethyl-3-(4-(2bromoethoxy)phenyl)acrylate (3) in 70\% (3.142 g) yield as white solid.

Melting point: $45-50{ }^{\circ} \mathrm{C}$; FTIR in $\mathrm{KBr}\left(\mathrm{cm}^{-1}\right): 627,645,810,1007,1054,1152,1173$, $1225,1280,1491,1597,1712,2845,2910,2997 ;{ }^{1} \mathrm{H}-\mathrm{NMR}$ in $\mathrm{CDCl}_{3}(400 \mathrm{MHz}) \delta=7.50(\mathrm{~d}$, $\left.1 \mathrm{H}, \mathrm{H}^{\beta} \mathrm{C}=\mathrm{CH}^{\alpha} \mathrm{R}, J 16 \mathrm{~Hz}\right), 7.65(\mathrm{~d}, 2 \mathrm{H}, J 8.4 \mathrm{~Hz}), 6.93(\mathrm{~d}, 2 \mathrm{H}, J 8.8 \mathrm{~Hz}), 6.34(\mathrm{~d}, 1 \mathrm{H}$, $\mathrm{H}^{\beta} \mathrm{C}=\mathrm{CH}^{\alpha} \mathrm{R}, J 15.6 \mathrm{~Hz}$ ), $4.34\left(\mathrm{t}, 2 \mathrm{H}, \mathrm{OCH}_{2}, J 6.2 \mathrm{~Hz}\right), 4.27$ (q, 2H, $\left.\mathrm{OCH}_{2}, J 7.2 \mathrm{~Hz}\right), 3.67$ (t, $\left.2 \mathrm{H}, \mathrm{BrCH}_{2}, J 6.2 \mathrm{~Hz}\right), 1.35\left(\mathrm{t}, 3 \mathrm{H}, \mathrm{CH}_{3}, J 7.0 \mathrm{~Hz}\right) ;{ }^{13} \mathrm{C}-\mathrm{NMR}$ in $\mathrm{CDCl}_{3}(100 \mathrm{MHz}) \delta=167.25$, $159.75,143.99,129.76,127.92,116.26,115.01,67.86,60.40,28.79,14.28$.

\subsubsection{Synthesis of (E)-ethyl 3-(p-(2-(piperidin-1-yl) ethoxy) phenyl) acrylate (1).}

A $500 \mathrm{~mL}$ clamped flask charged with commercially available piperidine (4) (2.55 g, $30 \mathrm{mmol})$ followed by addition of ethanol $(250 \mathrm{~mL})$. The solution was stirred at $25{ }^{\circ} \mathrm{C}$ for 5 minutes, followed by the addition of (E)-ethyl-3-(4-(2-bromoethoxy)phenyl)acrylate (3) (4.488 $\mathrm{g}, 15 \mathrm{mmol})$. Subsequently, $\mathrm{K}_{2} \mathrm{CO}_{3}(6.219 \mathrm{~g}, 45 \mathrm{mmol})$, then the catalytic portion of $\mathrm{KI}$ in water $(20 \mathrm{~mL})$ was introduced to the above reaction mixture [53]. The whole solution was refluxed up to $24 \mathrm{~h}$, and the progress of the reaction was observed using TLC. After $24 \mathrm{~h}$, the reaction flask was cooled to ambient condition. It was observed that white solid appeared at the bottom of the flask, which was separated using filter paper, and the resulting organic layer was evaporated using a rotary evaporator. Finally, obtained oil was again mixed with $\mathrm{CH}_{2} \mathrm{Cl}_{2}(100$ $\mathrm{mL})$ followed by treatment with $\mathrm{HCl}(0.5 \%)$ and $\mathrm{NaOH}(0.5 \%)$ and $\mathrm{H}_{2} \mathrm{O}(40 \mathrm{~mL})$. The solvent was exposed to $\mathrm{Na}_{2} \mathrm{SO}_{4}$. The solvent was removed using a rotary evaporator to afford product 1 in crude form. The residue of product 1 was then purified using the chromatographic technique by (60-120 mesh) silica gel and eluted with 30\% mixture of ethyl acetate in $n$-hexane as to isolate pure (E)-ethyl 3-(p-(2-(piperidin-1-yl) ethoxy) phenyl) acrylate (1) in 25\% yield $(1.14 \mathrm{~g})$ as a brown liquid.

FTIR neat ( $\left.\mathrm{cm}^{-1}\right):$ 670, 710, 873, 953, 1069, 1163, 1210, 1239, 1305, 1452, 1643, 1720 , 2940, 2963; ${ }^{1} \mathrm{H}-\mathrm{NMR}$ in $\mathrm{CDCl}_{3}(400 \mathrm{MHz}) \delta=7.55(\mathrm{~m}, 2 \mathrm{H}), 7.02\left(\mathrm{~d}, 1 \mathrm{H}, \mathrm{H}^{\beta} \mathrm{C}=\mathrm{CH}^{\alpha} \mathrm{R}\right), 6.51$ $(\mathrm{m}, 2 \mathrm{H}), 6.22\left(\mathrm{~d}, 1 \mathrm{H}, \mathrm{H}^{\beta} \mathrm{C}=\mathrm{CH}^{\alpha} \mathrm{R}\right), 3.45\left(\mathrm{q}, \mathrm{OCH}_{2}, 2 \mathrm{H}\right), 3.29\left(\mathrm{t}, \mathrm{OCH}_{2}, 2 \mathrm{H}\right), 2.34-1.64(\mathrm{~m}, 6 \mathrm{H}$, 
- $\mathrm{CH}_{2}$ of Pip) 1.04-0.67 (m, 6H, Piperidine 3,4,5-H) $0.52\left(\mathrm{t}, 3 \mathrm{H}, \mathrm{CH}_{3}\right) ;{ }^{13} \mathrm{C}-\mathrm{NMR}$ in $\mathrm{CDCl}_{3}(100$ $\mathrm{MHz}) \delta=171.17,157.45,139.03,130.06,128.73,113.19,78.01,65.33,59.33,57.41,54.46$, $26.41,24.50,13.51$.

\subsubsection{Synthesis of (E)-methyl 3-(p-(2-(piperidin-1-yl) ethoxy)-phenyl) acrylate (2).}

To the round bottom flask (E)-ethyl 3-(p-(2-(piperidin-1-yl) ethoxy)-phenyl) acrylate (1) $(0.607 \mathrm{~g}, 2 \mathrm{mmol})$ was dissolved in $\mathrm{MeOH}(15 \mathrm{~mL})$ and allowed to stir at $25^{\circ} \mathrm{C}$. To this solution, anhydrous $\mathrm{Na}_{2} \mathrm{CO}_{3}(0.212 \mathrm{~g}, 2 \mathrm{mmol})$ has been introduced and further heated to reflux $(5 \mathrm{~h})$, and the development of reaction was observed by TLC. Then the flask was cooled to 25 ${ }^{\circ} \mathrm{C}$, [54], and the solvent $(\mathrm{MeOH})$ was evaporated under vacuum. The obtained crude residue was dissolved with a mixture of EtOAc- $n$-hexane $(1: 1,10 \mathrm{~mL})$ followed by filtration in order to remove unwanted salts. Evaporation of the solvent gave crude product $\mathbf{2}$ as oil, which was subjected to chromatographic separation using (60-120 mesh) silica gel and elution with 30\% EtOAc: $n$-hexane to provide pure (E)-methyl 3-(p-(2-(piperidin-1-yl)ethoxy)-phenyl) acrylate (2) in $85 \%$ yield $(4.13 \mathrm{~g})$ as a brown oil.

FTIR neat $\left(\mathrm{cm}^{-1}\right): 665,715,745,868,945,1052,1155,1223,1247,1318,1460,1610$, 1645, 1715, 2923, 2976; ${ }^{1} \mathrm{H}-\mathrm{NMR}$ in $\mathrm{CDCl}_{3}(400 \mathrm{MHz}) \delta=7.55(\mathrm{~m}, 2 \mathrm{H}, \mathrm{Ar}-\mathrm{H}), 6.97(\mathrm{~m}, 2 \mathrm{H}$, Ar- $\mathrm{H}), 6.46\left(\mathrm{~d}, 1 \mathrm{H}, \mathrm{H}^{\beta} \mathrm{C}=\mathrm{CH}^{\alpha} \mathrm{R} J=8.0 \mathrm{~Hz}\right), 6.17\left(\mathrm{~d}, 1 \mathrm{H}, \mathrm{H}^{\beta} \mathrm{C}=\mathrm{CH}^{\alpha} \mathrm{R}, J 8.0 \mathrm{~Hz}\right), 3.40(\mathrm{t}, 2 \mathrm{H}$, $\left.\mathrm{O}_{-} \mathrm{CH}_{2}, J 8.0 \mathrm{~Hz}\right), 2.90$ (s, 3H, O-CH 3$), 2.26\left(\mathrm{t}, 2 \mathrm{H}, \mathrm{N}-\mathrm{CH}_{2}, J 7.2\right), 2.12\left(\mathrm{~m}, 2 \mathrm{H}, \mathrm{N}-\mathrm{CH}_{2}, J 7.2\right.$ $\mathrm{Hz} \& J 6.8 \mathrm{~Hz}), 1.90\left(\mathrm{~m}, 2 \mathrm{H}, \mathrm{N}-\mathrm{CH}_{2}\right), 1.12\left(\mathrm{~m}, 2 \mathrm{H}, \mathrm{R}-\mathrm{CH}_{2} \mathrm{R} J 6.8 \mathrm{~Hz}\right) ;{ }^{13} \mathrm{C}-\mathrm{NMR}$ in $\mathrm{CDCl}_{3}$ $(100 \mathrm{MHz}) \delta=171.48,157.42,143.70,130.10,128.55,114.21,113.17,78.01,65.02,57.40$, $54.43,26.49,24.54$.

\subsection{Evaluation of antibacterial activity.}

The in-vitro antibacterial screening of piperidine derivatives $\mathbf{1}$ and $\mathbf{2}$ were tested using two bacteria, namely Escherichia coli and Staphylococcus aureus, using the disc diffusion method. The disc diffusion method was performed with Whatman No.1 filter paper making discs measuring in $6 \mathrm{~mm}$ diameter. The compounds 1-2 and standard compounds were dissolved using ethanol with a concentration of $10 \mathrm{mg} / \mathrm{mL}$. The aliquots of $10 \mu \mathrm{L}$ and $20 \mu \mathrm{L}$ of the sample and standard solutions were added out to the discs, each in triplicate. The paper discs impregnated with the aliquots of $10 \mu \mathrm{L}$ and $20 \mu \mathrm{L}$ of the sample was transferred to a petri dish where the bacteria was cultivated. Sampling Petri dish was poured with a $20 \mathrm{~mL}$ MuellerHinton agar medium with $0.1 \mathrm{~mL}$ of the corresponding microorganism, which was spread through glass rod. Then the petri dish was incubated, keeping temperature $37^{\circ} \mathrm{C}$, for $24 \mathrm{~h}$. The antibacterial activity was calculated based on measuring the area of inhibition zone in diameter. All these tests were carried out in triplicate, and the mean of inhibition zone (dm), was calculated and presented as mean \pm standard deviation. The results obtained were compared with commercially available drug chloramphenicol as standard.

\subsubsection{Preparation of media.}

The in-vitro antibacterial screening of newly synthesized compounds $\mathbf{1}$ and $\mathbf{2}$ were tested against two bacterial species, namely Escherichia coli and Staphylococcus aureus, using the disc diffusion method.[55] Mueller-Hinton agar (MHA) was used as a medium to study biological assay, which was made by dissolving $3.8 \mathrm{~g}$ MHA and $100 \mathrm{~mL}$ distilled water. In order to make a homogeneous solution, the medium was heated gently with frequent agitation 
and then boiled for one minute. Later, the medium was autoclaved, keeping temperature 121 ${ }^{\circ} \mathrm{C}$, 15 min., which was further cooled to $25^{\circ} \mathrm{C}$. The $\mathrm{pH}$ of the medium was maintained at 7.1.

\section{Results and Discussion}

\subsection{Synthesis of designed piperidine derivatives.}

Both piperidine and cinnamic acid esters are associated with important biological properties. In the literature, there is no report to combine these two molecules as lead structures. Therefore we have chosen to synthesize new derivatives with a combination of piperidine and cinnamic acid esters based on the fact that they are highly bioactive substances. The retrosynthetic analysis of the newly designed piperidine derivatives $\mathbf{1}$ and $\mathbf{2}$ is represented in Scheme 1. In order to find the shortest synthetic route, the first disconnection could be possible between $\mathrm{C}-\mathrm{N}$ bond of target compounds ( $\mathbf{1}$ and $\mathbf{2}$ ), which resulted in the two fragments $\mathbf{3}$ and 4. These two intermediate $\mathbf{3}$ and $\mathbf{4}$ possibly join through nucleophilic substitution reaction to give target 1 .

Further, the intermediate 3 envisaged synthesizing by employing $\mathrm{O}$-alkylation reaction of 1,2-dibromoethane (5) with $\alpha$ - $\beta$-unsaturated ester $\mathbf{6}$. The $\alpha$ - $\beta$-unsaturated ester (6) could be further obtained from 4-hydroxylbenzaldehyde 8 via Wittig olefination reaction (7). While the target compound $\mathbf{2}$ could be achieved by a transesterification reaction of $\mathbf{1}$ with methanol.
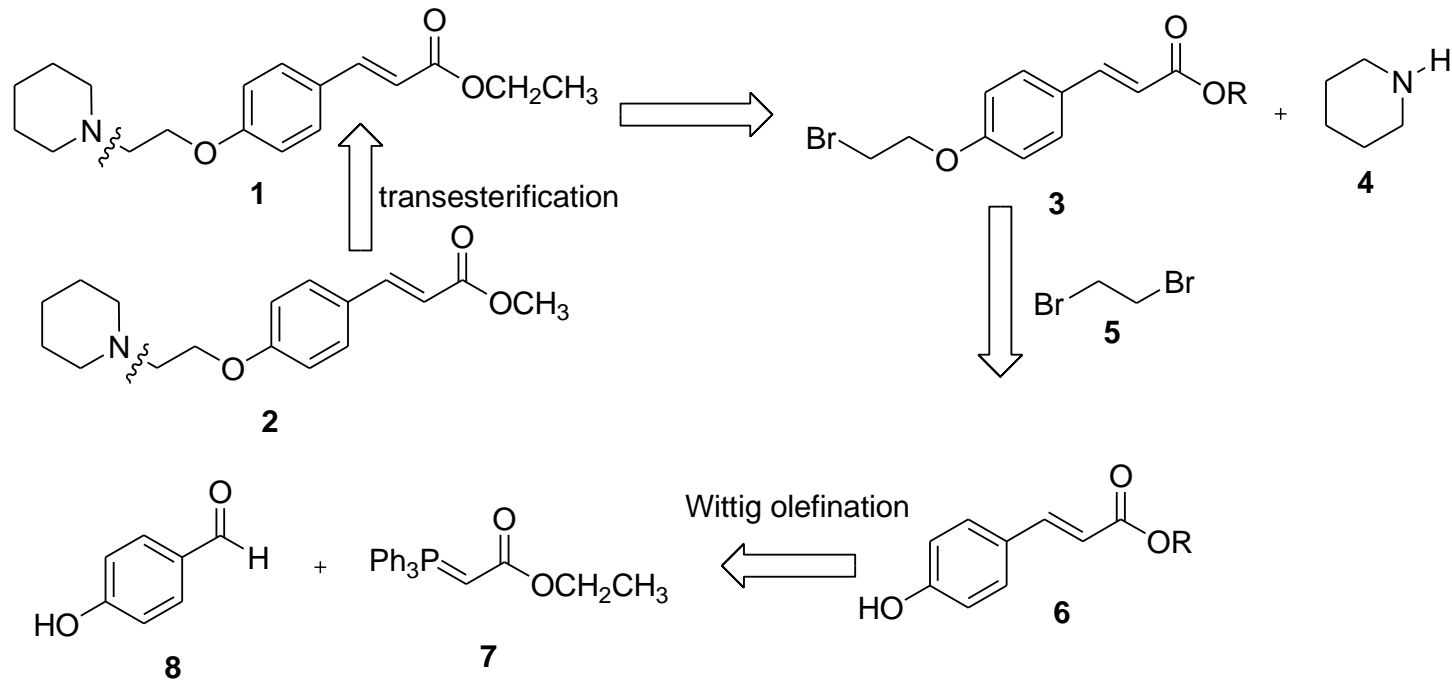

Scheme 1. Retrosynthetic analysis of designed piperidine derivatives.

The synthesis of desired piperidine compounds ( $\mathbf{1}$ and $\mathbf{2}$ ) was achieved by employing Wittig olefination, O-alkylation, and nucleophilic displacement reactions outlined in Scheme 2. The $\alpha-\beta$ unsaturated ester $\mathbf{6}$ was obtained by employing Wittig olefination of 4-hydroxy benzaldehyde (8) and phosphonate ester (7) in aqueous conditions at $90{ }^{\circ} \mathrm{C}$. Obtained $\alpha-\beta$ unsaturated ester $\mathbf{6}$ was then reacted with potassium hydroxide in DMF followed by alkylating agent 1,2-dibromoethane (5), which resulted in the formation of O-alkylated- $\alpha-\beta$ unsaturated ester in good yield. Finally, the introduction of piperidine moiety was accomplished by subjecting a nucleophilic substitution reaction. Thus, the reaction of O-alkylated- $\alpha-\beta$ unsaturated 3 with piperidine (4) under alkaline conditions $\mathrm{K}_{2} \mathrm{CO}_{3}$ and $\mathrm{KI}$ as a catalyst in the presence of aqueous ethanol produce the compound1 in good yield. 
<smiles>CCOC(=O)/C=C/c1ccc(O)cc1/C=C/C(=O)OCC</smiles><smiles>CCOC(=O)/C=C/c1ccc(OCCN2CCCCC2)cc1</smiles>

Scheme 2. Synthesis of (E)-ethyl 3-(p-(2-(piperidin-1-yl)ethoxy)phenyl)acrylate (1).

In order to synthesize compound $\mathbf{2}$ we utilized a transesterification strategy (Scheme 3). Therefore, compound $\mathbf{1}$ was treated with carbonate and methanol at ambient conditions to give the desired compound 2.<smiles>CCOC(=O)/C=C/c1ccc(OCCN2CCCCC2)cc1</smiles>

Scheme 3. Synthesis of (E)-methyl 3-(p-(2-(piperidin-1-yl) ethoxy)-phenyl)-acrylate (2).

\subsection{In-vitro antibacterial study.}

The antibacterial activities of the target products (1-2) were tested against pathogenic bacteria strains by using the disc diffusion method. The newly synthesized compounds were examined, against Staphylococcus aureus (gram-positive) and Escherichia coli (gramnegative) bacterial species grown in Mueller-Hinton agar (MHA). The results were compared with the commercially available antibiotic drug chloramphenicol as a reference. The test results obtained for the synthesized compounds $\mathbf{1}$ and 2, which was exposed to bacterias species Staphylococcus aureus and Escherichia coli, are presented in Table 1.

Table 1. Antibacterial activities of piperidine derived analogs . ${ }^{a}$

\begin{tabular}{c|c|c|c}
\multicolumn{4}{c}{ Antibacterial activities (Inhibition zone) } \\
\hline \multirow{2}{*}{ Samples } & Microorganism & \multicolumn{2}{|c}{$\begin{array}{c}\text { Inhibition zone in } \mathrm{mm} \\
\text { Concentration in } 10 \mathrm{mg} / \mathrm{ml}\end{array}$} \\
\hline \multirow{2}{*}{ Compound 1 } & & $10 \mu \mathrm{L}$ & $20 \mu \mathrm{L}$ \\
\hline \multirow{2}{*}{ Compound 2 } & Escherichia coli & $6 \pm 0.82$ & $9 \pm 1.41$ \\
\cline { 2 - 4 } & Staphylococcus aureus & $17 \pm 1.63$ & $22 \pm 4.32$ \\
\cline { 2 - 4 } & Escherichia coli & $8 \pm 0.82$ & $12 \pm 0$ \\
\hline \multirow{2}{*}{ Ethanol } & Staphylococcus aureus & $18 \pm 2.94$ & $24 \pm 3.26$ \\
\cline { 2 - 4 } & Escherichia coli & -- & -- \\
\hline Chloramphenicoloccus aureus & -- & $31 \pm 3.56$ \\
\cline { 2 - 4 } & Escherichia coli & $28 \pm 2.16$ & $23 \pm 2.45$
\end{tabular}

${ }^{a}$ Procedure for sample preparation is presented in the materials and methods section.

From Table 1, it was observed that piperidine derivatives were active against Staphylococcus aureus (gram-positive) and Escherichia coli (gram-negative) bacteria. From the inhibition data of synthesized compounds, compound $\mathbf{2}$ was more active than the corresponding analogs $\mathbf{1}$. Additionally, compound $\mathbf{2}$ showed good activity with respect to the commercially available standard drug chloramphenicol against gram-positive bacteria (Staphylococcus aureus). This activity resulted from the decrease of the hydrocarbon chain of the ester part. Compounds $\mathbf{1}$ and $\mathbf{2}$ were active against $E$. coli, gram-negative bacteria as compared with standard drug chloramphenicol. 


\section{Conclusions}

We have described the synthesis of new compounds namely (E)-ethyl 3-(p-(2(piperidin-1-yl)ethoxy)phenyl)acrylate (1) and (E)-methyl 3-(p-(2-(piperidin-1yl)ethoxy)phenyl)-acrylate (2) employing simple reaction conditions for example Wittig olefination, O-alkylation and nucleophilic displacement reaction. Furthermore, the synthesized compounds ( $\mathbf{1}$ and $\mathbf{2}$ ) were evaluated for their antibacterial activity using the disc diffusion method. The compounds $\mathbf{1}$ and $\mathbf{2}$ have been investigated employing Staphylococcus aureus (gram-positive) and Escherichia coli (gram-negative) bacteria, respectively. Interestingly, compound 1 showed moderate antibacterial activity, while compounds $\mathbf{2}$ displayed excellent antibacterial activity as compared with standard drugs.

\section{Funding}

This research work was supported by the PG Research grant of Mekelle University.

\section{Acknowledgments}

The authors are thankful to the Department of Chemistry and the College of Natural and Computation Science, Mekelle University, for providing research facilities to complete this work.

\section{Conflicts of Interest}

The authors declare no conflict of interest.

\section{References}

1. Eicher, T.; Hauptmann, S.; Speicher, A. Chemistry of Heterocycles: Structure, Reaction, Synthesis, and Applications. John Wiley \& Sons 2013.

2. Bozorov, K.; Zhao, J.; Aisa, H.A. 1,2,3-triazole-containing hybrids as leads in medicinal chemistry: A recent overview. Bioorganic \& Medicinal Chemistry 2019, 27, 3511-3531, https://doi.org/10.1016/j.bmc.2019.07.005.

3. Jordan, A.M.; Roughley, S.D. Drug discovery chemistry: a primer for the non-specialist. Drug Discovery Today 2009, 14, 731-744, https://doi.org/10.1016/j.drudis.2009.04.005.

4. Umesha, K.B.; Ningaiah, S.; Lingegowda, N.S.; Basavanna, V.; Doddamani, S. A new approach for the synthesis of 8-((1,3-diphenyl-4,5-dihydro-1H-pyrazole-5 yl)methoxy)quinoline: a novel lead for breast cancer chemotherapy. Biointerface Research in Applied Chemistry 2018, 8, 3744-3750.

5. Shahriari, S.; Monajjemi, M.; Zare, K. Penetrating to cell membrane bacteria by the efficiency of various antibiotics (clindamycin, metronidazole, azithromycin, sulfamethoxazole, baxdela, ticarcillin, and clavulanic acid) using S-NICS theory. Biointerface Research in Applied Chemistry 2018, 8, 3219-3223.

6. Overington, J. P.; Al-Lazikani, B.; Hopkins, A.L. How many drug targets are there? Nature Reviews \& Drug Discovery 2006, 5, 993-996, https://doi.org/10.1038/nrd2199.

7. Silverman, R.B.; Holladay, M.W. The Organic Chemistry of Drug Design and Drug Action. $3^{\text {rd }}$ ed. Elsevier. 2014.

8. Dias-Souza, M.V.; Dias, C.G.; Ferreira-Marcal, P.H. Interactions of natural products and antimicrobial drugs: investigations of a dark matter in chemistry. Biointerface Research in Applied Chemistry 2018, 8, 3259-3264.

9. Marcela, R.N.; Lauro, F.V.; Francisco, D.C.; Virginia, M.A.; Alejandra, G.E.E.; Patricia, H.V.; Laura, B.C.; Tomas, L.G.; Maria, L.R.; Lenin, H.H.; Eduardo, P.G.; Cabrera-TuzJhair, Yaritza, B.B.; Ortiz-AkeYazmin. Synthesis and theoretical activity evaluation of a new steroid-oxazolone derivative against COX1-1 and COX-2. Biointerface Research in Applied Chemistry 2019, 9, 4107-4113, https://doi.org/10.33263/BRIAC94.107113.

10. Royer, J. Asymmetric Synthesis of Nitrogen Heterocycles. Weinheim: WILEY-VCH Verlag GmbH \& Co.; 2009.

11. Afradi, N.; Foroughifar, N.; Qomi, M.; Pasdar, H. Folic acid-supported $\mathrm{Fe}_{3} \mathrm{O}_{4}$ magnetic nanoparticles as a new, highly effective heterogeneous biocatalyst for the synthesis of 3,4-dihydropyrimidine thiones and their 
in vitro investigation as antibacterial active agents. Biointerface Research in Applied Chemistry 2018, 8 , 3661-3669.

12. Van den Broek, S.A.M.W.; Meeuwissen, S.A.; van Delft, F.L.; Rutjes, F.P.J.T. Metathesis in Natural Product Synthesis; Wiley-VCH Verlag; 2010; p 45.

13. Dehbalaei, M.G.; Foroughifar, N.; Pasdar, H. Facile green one-pot synthesis of pyrano [2, 3-c] pyrazole and 1, 8-dioxo-decahydroacridine derivatives using graphene oxide as a carbocatalyst and their biological evaluation as potent antibacterial agents. Biointerface Research in Applied Chemistry 2018, 8, 3016-3022.

14. Cordell, G.A. The Alkaloids; Chemistry and Biology. Elsevier, Volume 69, 2010.

15. Taylor, R.D.; MacCoss, M.; Lawson, A.D.G. Rings in drugs. Journal of Medicinal Chemistry 2014, 57, 5845-5859, https://doi.org/10.1021/jm4017625.

16. Vitaku, E.; Smith, D.T.; Njardarson, J.T. Analysis of the Structural Diversity, Substitution Patterns, and Frequency of Nitrogen Heterocycles among U.S. FDA Approved Pharmaceuticals. Journal of Medicinal Chemistry 2014, 57, 10257-10274. https://doi.org/10.1021/jm501100b.

17. Zhang, T.Y. The evolving landscape of heterocycles in drugs and drug candidates. Advanced Heterocyclic Chemistry, 2017, 121, 1-12, https://doi.org/10.1016/bs.aihch.2016.05.001.

18. Balivand, Z.; Ghashang, M. NiO-SnO 2 nano-composite efficient catalyst for the preparation of substituted pyrano[3,2-c]quinolones and pyrano[3,2-c]chromene derivatives. Biointerface Research in Applied Chemistry 2018, 8, 3739-3743.

19. Mordini, A.; Reginato, G.; Calamante, M.; Zani, L. Stereoselective synthesis of polysubstituted piperazines and oxopiperazines. Useful building blocks in medicinal chemistry. Current Topics in Medicinal Chemistry 2014, 14, 1308-1316, https://doi.org/10.2174/1568026614666140423114013.

20. Mohamadpour, F.; Feilizadeh, M. Citric acid as a green and naturally biodegradable catalyst promoted convenient synthesis of polysubstituted dihydro-2-oxypyrrole derivatives via four-condensation reaction of dialkylacetylenedicarboxylate, formaldehyde and amines. Biointerface Research in Applied Chemistry 2019, 9, 4096-4100, https://doi.org/10.33263/BRIAC94.096100.

21. Mohamadpour, F. Ascorbic acid: a naturally green and efficient catalyst for one-pot synthesis of N-aryl-3aminodihydropyrrol-2-one-4-carboxylates under ambient temperature. Biointerface Research in Applied Chemistry 2019, 9, 4458-4462, https://doi.org/10.33263/BRIAC96.458462.

22. Cherukupalli, S.; Hampannavar, G.A.; Chinnam, S.; Chandrasekaran, B.; Sayyad, N.; Kayamba, F.; Aleti, R.R.; Karpoormath, R. An appraisal on synthetic and parmaceutical perspetives of pyrazolo[4,3d]pyrimidine scaffold. Bioorganic \& Medicinal Chemistry 2018, 26, 309-339, https://doi.org/10.1016/j.bmc.2017.10.012.

23. Taylor, A.P.; Robinson, R.P.; Fobian, Y.M.; Blakemore, D.C.; Jones, L.H.; Fadevi, O. Modern advacnces in heterocyclic chemistry in drug discoevry. Organic \& Biomolecular Chemistry 2016, 14, 6611-6637, https://doi.org/10.1039/C6OB00936K.

24. Chen, D.; Su, S.J.; Cao, Y. Nitrogen heterocycle-containing materials for highly efficient phosphorescent OLEDs with low operating voltage. Journal of Materials Chemistry C 2014, 2, 9565-9578, https://doi.org/10.1039/C4TC01941E.

25. Chen, Q.; Liang, X.; Du, J.; Wei, Z.; Zhang, Y.M.; Zhang, T.; Qin, T.; Gao, W.; Sheng, L.; Zhang, S.X.A. Construction of highly fluorescent $\mathrm{N}-\mathrm{O}$ seven-membered heterocycles via thermo-oxidation of oxazolidines. Journal of Materials Chemistry C 2019, 7, 8045-8052, https://doi.org/10.1039/C9TC01199D.

26. Anderson, E.B.; Long, T.E. Imidazole- and imidazolium-containing polymers for biology and materila sceince applications. Polymer, 2010, 51, 2447-2454. https://doi.org/10.1016/j-polymer.2010.02.006

27. Salim, S.; Hadibarata, T.; Elwina, E.; Dewi, R.; Alaraidh, I.A.; Al-Ghamdi, A.A.; Alsahli, A.A. Development of activated carbon from Eichhornia Crassipes via chemical activation and its application to remove a synthetic dye. Biointerface Research in Applied Chemistry 2019, 9, 4394-4400, https://doi.org/10.33263/BRIAC95.394400.

28. Levitz, A.; Marmarchi, F.; Henary, M. Introduction of various substitutions to the methine bridge od heptamethine cyanine dyes via substituted dianil linkers. Photochemical \& Photobiological Sciences 2018, 17, 1409-1416, https://doi.org/10.1039/C8PP00218E.

29. Khan, I.; Ibrar, A.; Ahmed, W. Synthetic approaches, functionalization and therapeutic potential of quinazoline and quinazolinone skeletons: The advances continue. European Journal of Medicinal Chemistry 2015, 90, 124-169, https://doi.org/10.1016/j.ejmech.2014.10.084.

30. Lovering, F.; Bikker, J.; Humblet, C. Escape from flatland: increasing saturation as an approach to improving clinical success. Journal of Medicinal Chemistry 2009, 52, 6752-6756, https://doi.org/10.1021/jm901241e.

31. Ritchie, T.J.; Macdonald, S.J.F.; Young, R.J.; Pickett, S.D. The impact of aromatic ring count on compound developability: further insights by examining carbo- and hetero-aromatic and -aliphatic ring types. Drug Discovery Today 2011, 16, 164-171, https://doi.org/10.1016/j.drudis.2009.07.014.

32. Zhao, H.; Zhao, W.B.; Zhu, J.S.; Jia, Y.M.; Yu, C.Y. An Efficient Synthesis of Aldohexose-Derived Piperidine Nitrones: Precursors of Piperidine Iminosugars. Molecules 2013, 18, 6021-6034, https://doi.org/10.3390/molecules18056021.

33. Mfuh, A.M.; Larionov, O.V. Heterocyclic N-Oxides - An Emerging Class of Therapeutic Agents. Current Medicinal Chemistry 2015, 22, 2819-2857, https://doi.org/10.2174/0929867322666150619104007. 
34. Sandmeier, T.; Krautwald, S.; Carreira, E.M. Stereoselective synthesis of piperidines by Iridium-catalyzed cyclocondensation. Angewandte Chemie Internation Edition 2017, 56, 11515-11519, https://doi.org/10.1002/anie.201706374.

35. Kubota, K.; Watanabe, Y.; Hayama, K.; Ito, H. Enantioselective synthesis of chiral piperidines via the stepwise dearomatization/borylation of pyridines. Journal of American Chemical Society 2016, 138, 43384331, https://doi.org/10.1021/jacs.6b01375.

36. Yamaguchi, R.; Fujita, K. I.; Zhu, M. Recent progress of new catalytic synthetic methods for nitrogen heterocycles nased on hydrogen transfer reactions. Heterocycles 2010, 81, 1093-1140.

37. Zhou, Y.; Gregor, V.E.; Ayida, B.K.; Winters, G.C.; Sun, Z.; Murphy, D.; Haley, G.; Bailey, D.; Froelich, J.M.; Fish, S.; Webber, S.E.; Hermann, T.; Wall, D. Synthesis and SAR of 3,5-diamino-piperidine derivatives: Novel antibacterial translation inhibitors as aminoglycoside mimetics. Bioorganic \& Medicinal Chemistry Letters 2007, 17, 1206-1210. https://doi.org/10.1016/j.bmcl.2006.12.024.

38. Chai, Y.; Wan, Z. L.; Wang, B.; Guo, H. Y.; Liu, M. L. Synthesis and in vitro antibacterial activity of 7-(4 alkoxyimino-3-amino-3-methylpiperidin-1-yl)fluoroquinolone derivatives. European Journal of Medicinal Chemistry 2009, 44, 4063-4069. https://doi.org/10.1016/j.ejmech.2009.04.041.

39. Taniguchi, T.; Ogasawara, K. A diastereo-controlled synthesis of (+)-febrifugine: A potent antimalarial piperidine alkaloid. Organic Letters 2000, 2, 3193-3195, https://doi.org/10.1021/ol006384f.

40. Hoa, B.; Cridera, A.M.; Stablesb, J.P. Synthesis and structure-activity relationships of potential anticonvulsants based on 2-piperidinecarboxylic acid and related pharmacophores. European Journal of Medicinal Chemistry 2001, 36, 265-286, https://doi.org/10.1016/S0223-5234(00)01206-X.

41. Alafeefy, A.M.; Kadi, A.A.; Al-Deeb, O.A.; El-Tahir, K.E.H.; Al-jaber, N.A. Synthesis, analgesic and antiinflammatory evaluation of some novel quinazoline derivatives. European Journal of Medicinal Chemistry 2010, 45, 4947-4952, https://doi.org/10.1016/j.ejmech.2010.07.067.

42. Kumari, P.; Kaur, S.; Kaur, J.; Bhatti, R.; Singh, P. Modification of the lead molecule: Tryptophan and piperidine appended triazines reversing inflammation and hyeperalgesia in rats. Bioorganic \& Medicinal Chemistry 2020, 28, 115246-115252. https://doi.org/10.1016/j.bmc.2019.115246.

43. Wardell, J.L.; Souza, M.V.N.; Wardell, S.M.S.V.; Lourenco, M.C.S. Mefloquine derivatives: Crystal structures and antitubercular activities of diphenyl[((R*,S*)-2,8-bis(trifluoromethyl)quinolin-4-yl)piperidin-2-yl-methanolato-O,N]boron and ( \pm )-erythro-mefloquinium tetraphenylborate solvates. Journal of Molecular Structure 2011, 990, 67-74, https://doi.org/10.1016/j.molstruc.2011.01.019.

44. Alluri, K.K.; Reshma, R.S.; Suraparaju, R.; Gottapu, S.; Sriram, D. Synthesis and evaluation of 4',5'dihydrospiro[piperidine-4,7'-thieno[2,3-c]pyran] analogues against both active and dormant Mycobacterium tuberculosis. Bioorganic \& Medicinal Chemistry 2018, 26, 1462-1469, https://doi.org/10.1016/j.bmc.2017.12.044.

45. Vardanyan, R. Piperidine-Based Drug Discovery. $1^{\text {st }}$ Edition, Elsevier; 2018; pp. 1-358.

46. Pontiki, E.; Hadjipavlou-Litina, D. Multi-Target cinnamic acids for oxidative stress and inflammation: Design, synthesis, biological evalutaion and modeling studies. Molecules 2019, 24, https://doi.org/10.3390/molecules24010012.

47. Sova, M. Antioxidant and antimicrobial activities of cinnamic acid derivatives. Mini Reviews in Medicinal Chemistry 2012, 12, 749-767, https://doi.org/10.2174/138955712801264792.

48. Shaikh, T.M.; Sudalai, A. A concise enantioselective synthesis of (+)-lentiginosine. Tetrahedron Asymmetry 2009, 20, 2287-2292, https://doi.org/10.1016/j.tetasy.2009.08.027.

49. Shaikh, T.M.; Sudalai, A. Enantioselective Synthesis of (+)- $\alpha$-Conhydrine and (-)-Sedamine by L-ProlineCatalysed $\alpha$-Aminooxylation. European Journal of Organic Chemistry 2010, 3437-3444, https://doi.org/10.1002/ejoc.201000169.

50. Shaikh, T.M.; Habtamu, D. Synthesis and Evaluation of Antimicrobial Activities of Novel N-substituted Indole Derivatives. Journal of Chemistry 2020, https://doi.org/10.1155/2020/4358453.

51. El-batta, A.; Jiang, C.; Zhao, W.; Anness, R.; Cooksy, A.L.; Bergdahl, M. Wittig Reactions in Water Media Employing Stabilized Ylides with Aldehydes. Synthesis of $\alpha, \beta$-Unsaturated Esters from Mixing Aldehydes, $\alpha$-Bromoesters, and $\mathrm{Ph}_{3} \mathrm{P}$ in Aqueous $\mathrm{NaHCO}_{3}$. Journal of Organic Chemistry 2007, 72, 5244-5259, https://doi.org/10.1021/jo070665k.

52. Mésangeau, C.; Amata, E.; Alsharif, W.; Seminerio, M.J.; Robson, M.J.; Matsumoto, R.R.; Poupaert, J.H.; McCurdy, C.R. Synthesis and Pharmacological Evaluation of Indole Based Sigma Receptor Ligands. European Journal of Medicinal Chemistry 2011, 46, 5154-5161, https://doi.org/10.1016/j.ejmech.2011.08.031.

53. Lazewska, D.; Kaleta, M.; Schwed, J.S.; Karcz, T.; Mogilski, S.; Latacz, G.; Olejarz, A.; Siwek, A.; Kubacka, M.; Lubelska, A.; Honkisz, E.; Handzlik, J.; Filipek, B.; Stark, H.; Kiec-Kononowicz, K. Biphenyloxy-Alkyl-Piperidine and Azepane Derivatives as Histamine H3 Receptor Ligands. Bioorganic \& Medicinal Chemistry 2017, 25, 5341-5354, https://doi.org/10.1016/j.bmc.2017.07.058.

54. Shinada, T.; Hamada, M.; Miyoshi, K.; Higashino, M.; Umezawa, T.; Ohfune, Y. Mild and Catalytic Transesterification Reaction Using $\mathrm{K}_{2} \mathrm{HPO}_{4}$ for the Synthesis of Methyl Esters. Synlett 2010, 14, 2141-2145, https://doi.org/10.1055/s-0030-1258491. 
55. Fyhrquist, P.; Virjamo, V.; Hiltunen, E.; Julkunen-Tiitto, R. Epidihydropinidine, the main piperidine alkaloid compound of Norway spruce (Picea abies) shows promising antibacterial and anti-Candida activity. Fitoterapia 2017, 117, 138-146, https://doi.org/10.1016/j.fitote.2017.01.011. 